\title{
ANALYSIS OF THE EXTERNAL AND INTERNAL LOAD IN $5 v 55$ LARGE SIDED GAMES: DIFFERENCES BETWEEN DIFFERENT SIZED FIELDS
}

\author{
Giacomo Cofano $^{1 \mathrm{AD}}$, Francesca D'Elia ${ }^{2 \mathrm{AD}}$, Andrea Piccinno ${ }^{3 \mathrm{BC}}$, Italo Sannicandro ${ }^{\mathrm{AD}}$ \\ ${ }^{1}$ University of Foggia \\ ${ }^{2}$ University of Salerno \\ ${ }^{3}$ Professional soccer strength and conditioning coach \\ Authors' Contribution: A - Study design; B - Data collection; C - Statistical analysis; D - Manuscript Preparation; E - Funds Collection
}

Corresponding Author: Italo Sannicandro, E-mail: italo.sannicandro@unifg.it

Accepted for Publication: October 29, 2021

Published: December 25, 2021

\section{DOI: 10.17309/tmfv.2021.4.08}

\begin{abstract}
The study purpose. The purpose of the study is to analyze and understand the internal and external load in Large Sided Games (LSG) exercises carried out on fields of different sizes, defined as Small - Large Sided Games (SLSG) and Big - Large Sided Games (BLSG), according to the different square meters assigned to each player.

Materials and methods. 22 professional soccer players (average age: $23.59 \pm 4.87$ years, weight: $77.8 \pm 7.6 \mathrm{~kg}$, height: $183.5 \pm 7.5 \mathrm{~cm}$, age training: $13.1 \pm 1.7)$. The LSG exercises were carried out on a $60 \mathrm{x} 54 \mathrm{~m}$ field $\left(270 \mathrm{~m}^{2} /\right.$ player $)$, defined as "small" (SLSG) and on a $65 \times 60 \mathrm{~m}$ field $\left(325 \mathrm{~m}^{2}\right.$ /player) defined as "big" (BLSG). During the two LSG exercises, the internal load and the external load were analyzed. LSG exercises were performed with 4 sets of 5 minutes each, with 2 minutes of passive recovery between each set.

Results. The results of the internal load analysis show how the LSG carried out on a SLSG field provides higher and more significant HR values ( $\mathrm{p}<0.0005)$ than those emerged during the exercise carried out on a BLSG field. The RPE value is also higher during the SLSG, although statistically no significant difference appears. The analysis of the external load in relation with the observed parameters shows higher values in the BLSG, except for the number of accelerations.

Conclusions. In terms of external and internal load, the results of this study showed how the difference of $55 \mathrm{~m}^{2} / \mathrm{player}$ can radically change the configuration of the two exercises. These differences allow to use both dimensions within a micro-cycle, but in sessions with different goals. The most appropriate sessions for LSGs are the first post-match session in which the rest day is not gone and the fourth session 3 days before the match.

Keywords: large sided games, external load, internal load, soccer, professional soccer players.
\end{abstract}

\section{Introduction}

Over the years, the specific soccer training has undergone significant changes (Esposito et al., 2019; Raiola \& Altavilla, 2020) due to the increasing knowledge and the focus on new exercises, useful for training technical, tactical and physical aspects.

General exercises related to the development of metabolic aspects are often integrated with sport-specific exercises capable of meeting the demands of the ever-changing performance model (Ceruso et al., 2019; D'Isanto et al., 2019).

These sport-specific exercises are called Small-Sided Games (SSG). Over the years, in the literature, SSGs have

(C) Cofano, G., D’Elia, F., Piccinno, A., \& Sannicandro, I., 2021. been identified with different names, such as skill-based conditioning games (Gabbett, 2006), game-based training (Gabbett et al., 2009), conditioning games on small dimensions (Davids et al., 2013) or simply as modified games (HillHaas et al., 2011). These games are soccer-specific exercises played on small fields with modified rules involving fewer players than traditional and official matches (Hill-Haas et al., 2011). The SSGs meet all the specific demands related to soccer and represent a resourceful solution to improve the efficiency of the training process (Beato et al., 2018) in both young and adult soccer players.

Over the years, in the scientific literature numerous articles, reviews and texts have been published, describing what happens both in the internal and in the external load during these exercises carried out on a reduced field (Halouani et al., 2014; Hill-Haas et al., 2011). 
Furthermore, the studies and experiences related to the SSGs identified the peculiar characteristics of these exercises, leading to a further internal subdivision that proposes to divide them into small-sided, medium-sided and large-sided games (Clemente et al., 2019; Goto \& King, 2019).

This classification offers a precise and detailed organization of a micro-cycle that has a vital meaning for the goal of the entire training session and even in relation to the main objective (technical-tactical or physical) of the exercises carried out with a ball.

Indeed, both the size and spatial configuration constitute variables that clearly characterize and distinguish this type of exercises (Coutinho et al., 2019; Sannicandro, 2019).

The classification of SSGs (small, medium or large) can be related to the field size used for each format (Rampinini et al., 2007a) or just to the format (Clemente et al., 2019; Goto \& King, 2019).

According to the size, the distinction related to the square meters assigned to each player allows to train different skills or the same skill but with different intensity.

Instead, according to the format, $1 \mathrm{vs} 1$ to $3 \mathrm{vs} 3$ games are considered small, 5vs5 and 6vs6 games are considered medium and $8 \mathrm{vs} 8,9 \mathrm{vs} 9$ and $10 \mathrm{vs} 10$ games are considered large.

It can be noticed that the $4 \mathrm{vs} 4$ and $7 \mathrm{vs} 7$ formats have not been mentioned. They are considered intermediate because a $4 \mathrm{vs} 4$ game can be both small and medium and a 7vs7 game can be both medium and large.

However, a further classification and distinction can also be found in the scientific literature. Leaving out the 1vs1, 2vs2 formats, some authors (Owen et al., 2014) have modified the different formats, considering the inclusion of the goalkeeper (GK) and adjusting the playing field dimensions considered appropriate according to the research group goals.

The analysis of the SSGs also involves the dimensions attributed to each format: the literature has begun to consider the density of players per square meter, introducing the theme of large-sided games in which each player is assigned approximately 200 square meters (Casamichana et al., 2018; Castagna et al., 2019; Castellano et al., 2015; Castillo et al., 2020; Goto \& King, 2019; Riboli et al., 2020; Zurutuza et al., 2020).

However, if we actually consider the size of a playing field, few authors have described what occurs when a player is assigned proper field densities during an official match, i.e. about 325 square meters for professionals (Goto \& King, 2019; Riboli et al., 2020) and about 270 square meters for non-professionals (Castagna et al., 2019; Castellano et al., 2015).

When the analysis focused on densities per player exceeding 300 square meters, some authors did not consider the presence of goalkeepers, effectively altering the final result (Casamichana et al., 2018; Riboli et al., 2020).

Only by including the goalkeeper in the square meters computation, due to the position in space occupied and the role in the defence/occupation of the space itself, it is possible to correctly define a large sided game (LSG).

This space must be assigned according to the different official sizes of the playing field for professional and nonprofessional players.

The purpose of the study is to analyse and understand the internal and external load on LSG exercises carried out on fields of different sizes, defined as Small - Large Sided Games (SLSG) and Big - Large Sided Games (BLSG), according to the different square meters assigned to each player.

\section{Materials and methods}

\section{Study participants}

22 professional soccer players (20 movement players and 2 goalkeepers) from Serie C team (season 2020/2021) participated in the study (average age: $23.59 \pm 4.87$ years, weight: $77.8 \pm 7.6 \mathrm{~kg}$; height: $183.5 \pm 7.5 \mathrm{~cm}$, age training: $13,1 \pm 1,7)$. The goalkeepers were not considered in the data collection of the external and internal load. The study included all the players who at the time of the survey did not report injuries, had been training and participating in matches for at least 3 weeks. All soccer players were used to work with GPS monitoring systems and heart rate monitors. The study was carried out respecting the principles contained in the Declaration of Helsinki.

\section{Study organization}

For the analysis of the internal load, heart rate (HR) and perception of effort (RPE) parameters were measured. The HR detection was conducted with a telemetry system and heart rate monitors (Polar Electro Oy, Kempele, Finland). The analysed values are the average HR and the HR peak, both in beats per minute (bpm) and in percentage referred to the maximum HR.

For the detection of the RPE - Ratings of Perceived Exertion, the Borg scale CR10 was used (Borg, 1982). During the two LSG exercises, the players were monitored using global positioning system (GPS) instrumentation at $18.18 \mathrm{~Hz}$ (GPEXE ${ }^{\bullet}$ SYSTEM, EXELIO srl, Udine, Italy) recently validated (Hoppe et al., 2018). The parameters detected and examined are the total distance covered $(\mathrm{m})$, the distance covered per minute $(\mathrm{m})$, the peak speed $(\mathrm{km} / \mathrm{h})$, the average metabolic power $(\mathrm{W} / \mathrm{kg})$, the average metabolic power $(\mathrm{W} / \mathrm{kg}$ ) expressed during the active phases (MPE avg power) and during the recovery phases (MPE rec avg power), the number of accelerations $(>2 \mathrm{~m} / \mathrm{s})$ and decelerations $(<-2 \mathrm{~m} / \mathrm{s})$ and the equivalent distance $(\mathrm{m})$. The covered distance was also monitored at different speeds: walking $(<7.30 \mathrm{~km} / \mathrm{h})$, running at low intensity $(7.30-14.50 \mathrm{~km} / \mathrm{h})$, running at moderate intensity $(14.50-19.90 \mathrm{~km} / \mathrm{h})$, running at high intensity $(19.90-25.20 \mathrm{~km} / \mathrm{h})$ and in sprints with speed $>25.2 \mathrm{~km} / \mathrm{h}$ (Rampinini et al., 2007b) and the covered distance with different power intensities: low power $(<20.00 \mathrm{~W} / \mathrm{kg})$, high power $(20.00-35.00 \mathrm{~W} / \mathrm{kg})$, very high power $(35.00-50.00 \mathrm{~W} / \mathrm{kg})$ and maximum power that is $>50 \mathrm{~W} / \mathrm{kg}$ (Osgnach et al., 2010).

The exercises of LSG 5vs5 + 2 goalkeepers were carried out on a natural grass playing field and the measurements of the two fields used reflected those of the competition fields for professionals $(105 \times 68 \mathrm{~m}$, FIFA data) for the big field and non-professionals $(100 \times 60 \mathrm{~m})$ for the small field.

Therefore, the SSG exercises were carried out on a $60 \times$ $54 \mathrm{~m}$ field $\left(270 \mathrm{~m}^{2} /\right.$ player $)$, defined as "small" (SLSG) and on a $65 \times 60 \mathrm{~m}$ field $\left(325 \mathrm{~m}^{2} /\right.$ player $)$ defined as "big "(BLSG). For the exercises, No. 5 soccer balls were used, positioned both inside the goal and outside the perimeter of the field to speed up the match when the ball ended out. Regular goals 
Table 1. The SSG formats used in the study

\begin{tabular}{lcc}
\hline \multicolumn{1}{c}{ Indicator } & SMALL LSG & BIG LSG \\
\hline Number of Bouts & 4 & 4 \\
Bout Duration $(\mathrm{min})$ & 5 & 5 \\
Resting Duration $(\mathrm{min})$ & 2 & 2 \\
Pitch Dimension $(\mathrm{m} \times \mathrm{m})$ & $60 \times 54$ & $65 \times 60$ \\
Relative Pitch Size $\left(\mathrm{m}^{2}\right)$ & $1: 270$ & $1: 325$ \\
Goalkeeper & YES & YES \\
Specific Rules & max 3 touches & max 3 touches \\
Coach Encouragement & YES & YES \\
\hline
\end{tabular}

$(7.32 \times 2.44 \mathrm{~m})$ were used. LSG's exercises were carried out with the encouragement from the technical staff and with the limitation of consecutive touches (3) of the ball. The characteristics of the LSGs are summarized in table 1.

After the warm-up, players began with LSG exercises: 4 sets of 5 minutes each, with 2 minutes of passive recovery between each set. During the whole exercise, players were monitored through the use of a heart rate monitor in telemetry and GPS instruments. At the end of each exercise, the RPE value was analysed individually.

The exercises were carried out in different days, with a recovery pause of at least 48 hours, at the same hour and temperature $\left(22.3^{\circ} \mathrm{C}\right)$.

\section{Statistical analysis}

Descriptive statistics $(M \pm S D)$ was applied to all observed variables; Student's t-test for paired data was used to verify the existence of statistically significant differences between the average values obtained using the Statistical Package for Social Sciences (SPSS 15.0 for Windows) software.
Significance was set at $\mathrm{p}<0.05$. Cohen's $\mathrm{d}$ was used to verify the effect size index (Cohen, 1992).

\section{Results}

The results of the internal load analysis show how the LSG carried out on a SLSG field provides higher and significant $H R$ values $(p<0.0005)$ than those emerged during the exercise carried out on a BLSG field. Specifically, the peak HR value $(\mathrm{bpm})(188.75 \pm 5.3$ vs $182.5 \pm 6.09, \mathrm{~d}=1.01)$, the peak\% HRmax $(94.75 \pm 2,33$ vs $91.75 \pm 2.65, \mathrm{~d}=1.14)$, average HR (bpm) $(173.75 \pm 7.65$ vs $165 \pm 8.17, \mathrm{~d}=1.46)$ and average $H R$ of $87 \pm 3.77$ vs $82.75 \pm 3.65, d=1.23)$. The RPE value is also higher during the SLSG $(8.1 \pm 1.21$ vs $7.8 \pm 1.19)$ although statistically, no significant difference appears.

On the other hand, the analysis of the external load in relation with the observed parameters shows higher values in the BLSG, except for the number of accelerations. All the parameters show statistically significant differences between the two fields used, except for the distance travelled at low intensity, which did not provide statistical significance. The results of the external load and relative significance are summarized and described in table 2.

\section{Discussion}

The study wanted to describe the effects on internal and external load related to two different large sided games formats.

In the literature, this appears to be the first study addressing the issue of SLSG and BLSG in soccer.

From the analysis of the internal and external load of the LSG during the 5vs5 LSG format carried out on two defined fields (SLSG and BLSG), it can be seen that the two exercises are very different, according to the different and statistically

Table 2. Results of external load recorded in the SLSD and in BLSG

\begin{tabular}{|c|c|c|c|}
\hline Indicator & 5vs5 SLSG & 5vs5 BLSG & Cohen's d \\
\hline Total distance $(\mathrm{m})$ & $2753.98 \pm 135.87$ & $2986.96 \pm 244.24^{\star * *}$ & -1.61 \\
\hline Distance/min (m) & $137.69 \pm 6.79$ & $149.34 \pm 12.21^{* * *}$ & -1.61 \\
\hline Maximum speed $(\mathrm{km} / \mathrm{h})$ & $26.25 \pm 1.13$ & $27.58 \pm .9^{* * *}$ & -1.9 \\
\hline Avg Metabolic power $(\mathrm{W} / \mathrm{kg})$ & $11.25 \pm .92$ & $12.11 \pm 1.3^{\star * *}$ & -1.3 \\
\hline MPE avg power $(\mathrm{W} / \mathrm{kg})$ & $21.36 \pm .9$ & $22.63 \pm .87^{* * *}$ & -0.95 \\
\hline MPE rec avg power $(\mathrm{W} / \mathrm{kg})$ & $6.72 \pm .29$ & $7.16 \pm .76^{*}$ & -0.58 \\
\hline Acceleration $\left(\mathrm{n}^{\circ}\right)$ & $30.8 \pm 9.95^{\star}$ & $27.6 \pm 5.75$ & 0.53 \\
\hline Deceleration $\left(\mathrm{n}^{\circ}\right)$ & $28 \pm 6.35$ & $32.2 \pm 4.37^{* * *}$ & -1.36 \\
\hline Equivalent distance (m) & $3223.36 \pm 210.73$ & $3501.4 \pm 300.24^{* * *}$ & -1.99 \\
\hline Walking $(\mathrm{m})$ & $722.66 \pm 63$ & $676.28 \pm 93.73^{\star * *}$ & 0.73 \\
\hline Low intensity running (m) & $1307.6 \pm 98.17$ & $1382.7 \pm 173.72$ & \\
\hline Moderate intensity running $(\mathrm{m})$ & $538.64 \pm 83.12$ & $652.82 \pm 142.28^{\star * *}$ & -1.45 \\
\hline High intensity running $(\mathrm{m})$ & $176.48 \pm 48.57$ & $241.54 \pm 73.92^{* * *}$ & -1.08 \\
\hline Sprint running $(\mathrm{m})$ & $8.96 \pm 9.29$ & $33.84 \pm 20.72^{\star * *}$ & -1.21 \\
\hline Distance low-power (m) & $1933.36 \pm 26.66$ & $2009.8 \pm 77.28^{* * *}$ & -1.12 \\
\hline Distance high-power (m) & $535.26 \pm 80.75$ & $619.96 \pm 144.26^{* * *}$ & -0.77 \\
\hline Distance very high-power (m) & $203.92 \pm 30.92$ & $248.96 \pm 27.58^{* * *}$ & -1.64 \\
\hline Distance maximum power $(\mathrm{m})$ & $81.84 \pm 33.41$ & $108.44 \pm 30.98^{* * *}$ & -1.30 \\
\hline
\end{tabular}

${ }^{*} \mathrm{p}<.05 ;{ }^{* *} \mathrm{p}<.01 ;{ }^{* * *} \mathrm{p}<.005$ 
significant values emerging from the parameters taken into consideration. The $5 \mathrm{vs} 5$ on the SLSG field provides a higher and significant HR value $(\mathrm{p}<0.0005)$ than the BLSG field even if each player is assigned lower density $\left(55 \mathrm{~m}^{2} /\right.$ player $)$.

This difference can be explained following what has already been described during the performance of SSG in small fields, in which the players seem to be more involved in the game (Halouani et al., 2017) and consequently have less time to recover, after an intense effort.

The hypothesis related to the HR is confirmed by the analysis of the RPE in the SLSG, which provides an increasingly higher, albeit non-significant value compared to the BLSG, confirming how the effort perceived is related to the intensity of the exercise.

Analysing the external load, it is clear that the BLSG is an exercise that provides higher values in all the observed parameters, except for the distance travelled at very low intensity and for the number of accelerations that are significantly different $(\mathrm{p}<0.05)$, and a $\mathrm{d}=0.53$ effect size medium, in favour of the SLSG.

The distance travelled at moderate $(\mathrm{p}<0.0005$; large $\mathrm{d}=-1.45489)$, high $(\mathrm{p}<0.0005$; large $\mathrm{d}=-1.08689)$ and very high intensity $(\mathrm{p}<0.0005$; large $\mathrm{d}=-1.21948)$ demonstrates how the use of a larger field allows players to reach high running speeds.

The analysis of the power at different intensities follows the same trend seen with speed: both the distance travelled at high power $(\mathrm{p}<0.0005$; medium $\mathrm{d}=-0.77257)$, the distance travelled at very high power $(\mathrm{p}<0.0005$; large $\mathrm{d}=-1.64614)$, and the distance travelled at maximum power $(\mathrm{p}<0.0005$; large $d=-1.30109$ ) are most stressed in a BLSG.

The values of the average metabolic power and of the metabolic power expressed both during the active and the recovery phases, although higher and significant $(\mathrm{p}<0.0005)$ in the BLSG, suggest how both exercises are able to produce high power values when compared to those detected during matches played by both adult and young players (Castagna et al., 2017; Hoppe et al., 2017).

As for the total distance travelled, this value is higher and significant in the BLSG $(\mathrm{p}<0.0005$; large $\mathrm{d}=-1.6167)$.

The results obtained in this study provide higher values than those already present in the literature, both when the same format was analysed but with a different density of $200 \mathrm{~m}^{2} /$ player (Castillo et al., 2020) and when different formats were analysed (6vs6 and 8vs8 + goalkeepers) with a density of $300 \mathrm{~m} 2$ /player (Castellano et al., 2015).

The same values, on the other hand, are lower than those provided by another study that used the same format and the same density of the BLSG but with a total time of the exercise (35 minutes vs 20 minutes), higher than the time calculated in this analysis (Goto \& King, 2019).

Considering these disparities, the exercise volumes used and monitored in the literature should be standardized in order to carry out more in-depth comparisons.

The maximum speed detected in this study, both in the SLSG $(26.25 \pm 1.13 \mathrm{~km} / \mathrm{h})$ and in the BLSG $(27.58 \pm 0.9 \mathrm{~km} / \mathrm{h})$, reveals a significant difference between the two playing fields used ( $p<0.0005$; large $d=-1.9061)$, and is higher than what can be found in the literature (Casamichana et al., 2018; Castillo et al., 2020; Zurutuza et al., 2020).

Another interesting fact that emerged from the study is the value related to the meters per minute travelled. Similarly, in this case there is a significant difference between SLSG and BLSG (137.69 \pm 6.79 vs $149.34 \pm 12.21, \mathrm{p}<0.0005$; large $\mathrm{d}=-1.61686)$. Both values are higher, compared with those detected by some authors who studied the $7 \mathrm{vs} 7$ to $9 \mathrm{vs} 9$ formats, with a density between 235 and $272 \mathrm{~m}^{2} /$ player (Zurutuza et al., 2020).

They are also higher when compared with results emerging from studies with the same format and a similar density (330 $\mathrm{m}^{2}$ /player) (Casamichana et al., 2018).

Probably the sample observed in this study for the relative level of performance (professional soccer players with high age training) are able to express better performance at maximum acceleration.

In both exercises, the distance travelled at moderate intensity $(>14.50 \mathrm{~km} / \mathrm{h})$ appears to be higher than the values shown in another study (Goto \& King, 2019) which used the same format, the same density but lasted longer.

The results related to the distance travelled at high power $(>20 \mathrm{~W} / \mathrm{kg})$ appear more complex because the values of the SLSG $(821.02 \mathrm{~m})$ and the BLSG $(977.36 \mathrm{~m})$ are lower than those found in the literature, where a value equal to $1050 \mathrm{~m}$ can be found (Goto \& King, 2019): once again, the different duration may have determined these differences in terms of power. Apparently, the metabolic power values are not superimposable with those related to speed.

If we consider the values related to the parameters of $\% \mathrm{HR}$ max and \% average $\mathrm{HR}$, the results obtained in this study $(94.75 \pm 2.33 \%$ and $87 \pm 3.77 \%$ in the SLSG and 91.75 $\pm 2.65 \%, 82.75 \pm 3.65 \%$ in the BLSG) are consistent with what has been identified in the literature, with formats where each player was assigned about 300 square meters (Castellano et al., 2015) or slightly higher than other recent studies (Casamichana et al., 2018). The same considerations are to be formulated for the RPE values that are slightly higher than those described in the literature (Casamichana et al., 2018).

\section{Conclusions}

In terms of external and internal load, the results of this study showed how the difference of $55 \mathrm{~m}^{2} /$ player can radically change the configuration of the two exercises.

These differences allow to use both dimensions within a micro-cycle, but in sessions with different goals.

In fact, in relation to the two dimensions of the field used, it is advisable to use the large field in the first weekly session on the day following the match; while the small field in the fourth weekly session 3 days before the match.

The large sided games considering the square meters per player rather than focusing on the format appear functional if the goal is a game intensity similar to what occurs in the official match.

Further analysis, however, need to be conducted in order to figure out which duration can better meet the demands of the player's performance model. Finally, a further study could also define the differences between the various roles employed in the SSG exercises.

\section{Conflict of interest}

The authors declare no conflict of interest.

\section{References}

Esposito, G., Ceruso, R., \& D’Elia, F. (2019). The importance of a technical-coordinative work with psychokinetic elements in the youth sectors of soccer academies. 
Journal of Physical Education and Sport, 19(Suppl. 5), 1843-1851. https://doi.org/10.7752/jpes.2019.s5272

Raiola, G., \& Altavilla, G. (2020). Testing motor skills, general and special coordinative, in young soccer. Journal of Human Sport \& Exercise, 15(Supplementary Issue 1Proc Winter event Costa Blanca), 206-212.

Ceruso, R., Esposito, G., \& D’Elia, F. (2019) Coordination attached to the qualitative aspects of football. Journal of Physical Education and Sport, 19(Suppl. 5), 1773-1776. https://doi.org/10.7752/jpes.2019.s5260

D’Isanto, T., D’Elia, F., Raiola, G., \& Altavilla, G. (2019). Assessment of sport performance: theoretical aspects and practical indications. Sport Mont, 17(1), 79-82. https://doi.org/10.26773/smj.190214

Gabbett T. J. (2006). Skill-based conditioning games as an alternative to traditional conditioning for rugby league players. Journal of strength and conditioning research, 20(2), 309-315. https://doi.org/10.1519/R-17655.1

Gabbett, T., Jenkins, D., \& Abernethy, B. (2009). Game-Based Training for Improving Skill and Physical Fitness in Team Sport Athletes. International Journal of Sports Science \& Coaching, 4(2), 273-283. https://doi.org/10.1260/174795409788549553

Davids, K., Araújo, D., Correia, V., \& Vilar, L. (2013). How small-sided and conditioned games enhance acquisition of movement and decision-making skills. Exercise and sport sciences reviews, 41(3), 154-161. https://doi.org/10.1097/JES.0b013e318292f3ec

Hill-Haas, S. V., Dawson, B., Impellizzeri, F. M., \& Coutts, A. J. (2011). Physiology of small-sided games training in football: a systematic review. Sports medicine (Auckland, N.Z.), 41(3), 199-220.

https://doi.org/10.2165/11539740-000000000-00000

Beato, M., Jamil, M., \& Devereux, G. (2018). Reliability of internal and external load parameters in recreational football (soccer) for health. Research in sports medicine (Print), 26(2), 244-250. https://doi.org/10.1080/15438627.2018.1431532

Halouani, J., Chtourou, H., Gabbett, T., Chaouachi, A., \& Chamari, K. (2014). Small-sided games in team sports training: a brief review. Journal of strength and conditioning research, 28(12), 3594-3618. https://doi.org/10.1519/JSC.0000000000000564

Clemente, F. M., Sarmento, H., Rabbani, A., Van Der Linden, C., Kargarfard, M., \& Costa, I. T. (2019). Variations of external load variables between medium- and large-sided soccer games in professional players. Research in sports medicine (Print), 27(1), 50-59.

https://doi.org/10.1080/15438627.2018.1511560

Goto, H., \& King, J. A. (2019). High-Intensity Demands of 6-a-Side Small-Sided Games and 11-a-Side Matches in Youth Soccer Players. Pediatric exercise science, 31(1), 8590. https://doi.org/10.1123/pes.2018-0122

Coutinho, D., Gonçalves, B., Santos, S., Travassos, B., Wong, D. P., \& Sampaio, J. (2019). Effects of the pitch configuration design on players' physical performance and movement behaviour during soccer small-sided games. Research in sports medicine (Print), 27(3), 298-313. https://doi.org/10.1080/15438627.2018.1544133

Sannicandro, I. (2019). Small-Sided Games configuration pitch and external motor load relationship in young soccer players: narrative literature review. Journal of Physical
Education and Sport, 19(Suppl. 5), 1989-1993. https://doi.org/10.7752/jpes.2019.s5296

Rampinini, E., Impellizzeri, F. M., Castagna, C., Abt, G., Chamari, K., Sassi, A., \& Marcora, S. M. (2007a). Factors influencing physiological responses to small-sided soccer games. Journal of sports sciences, 25(6), 659-666. https://doi.org/10.1080/02640410600811858

Owen, A. L., Wong, D. P., Paul, D., \& Dellal, A. (2014). Physical and technical comparisons between varioussided games within professional soccer. International journal of sports medicine, 35(4), 286-292. https://doi.org/10.1055/s-0033-1351333

Casamichana, D., Bradley, P. S., \& Castellano, J. (2018). Influence of the Varied Pitch Shape on Soccer Players Physiological Responses and Time-Motion Characteristics During Small-Sided Games. Journal of human kinetics, 64, 171-180. https://doi.org/10.1515/hukin-2017-0192

Castagna, C., D’Ottavio, S., Cappelli, S., \& Araújo Póvoas, S. C. (2019). The Effects of Long Sprint Ability-Oriented Small-Sided Games Using Different Ratios of Players to Pitch Area on Internal and External Load in Soccer Players. International journal of sports physiology and performance, 1265-1272. Advance online publication. https://doi.org/10.1123/ijspp.2018-0645

Castellano, J., Puente, A., Echeazarra, I., \& Casamichana, D. (2015). Influence of the number of players and the relative pitch area per player on heart rate and physical demands in youth soccer. Journal of strength and conditioning research, 29(6), 1683-1691. https://doi.org/10.1519/JSC.0000000000000788

Castillo, D., Raya-González, J., Manuel Clemente, F., \& Yanci, J. (2020). The influence of youth soccer players' sprint performance on the different sided games' external load using GPS devices. Research in sports medicine (Print), 28(2), 194-205. https://doi.org/10.1080/15438627.2019.1643726

Riboli, A., Coratella, G., Rampichini, S., Cé, E., \& Esposito, F. (2020). Area per player in small-sided games to replicate the external load and estimated physiological match demands in elite soccer players. PloS one, 15(9), e0229194. https://doi.org/10.1371/journal.pone.0229194

Borg G. A. (1982). Psychophysical bases of perceived exertion. Medicine and science in sports and exercise, 14(5), 377-381.

Zurutuza, U., Castellano, J., Echeazarra, I., Guridi, I., \& Casamichana, D. (2020). Selecting Training-Load Measures to Explain Variability in Football Training Games. Frontiers in psychology, 10, 2897. https://doi.org/10.3389/fpsyg.2019.02897

Hoppe, M. W., Baumgart, C., Polglaze, T., \& Freiwald, J. (2018). Validity and reliability of GPS and LPS for measuring distances covered and sprint mechanical properties in team sports. PloS one, 13(2), e0192708. https://doi.org/10.1371/journal.pone.0192708

Osgnach, C., Poser, S., Bernardini, R., Rinaldo, R., \& di Prampero, P. E. (2010). Energy cost and metabolic power in elite soccer: a new match analysis approach. Medicine and science in sports and exercise, 42(1), 170-178. https://doi.org/10.1249/MSS.0b013e3181ae5cfd

Cohen J. (1992). A power primer. Psychological bulletin, 112(1), 155-159. https://doi.org/10.1037//0033-2909.112.1.155

Rampinini, E., Bishop, D., Marcora, S. M., Ferrari Bravo, D., Sassi, R., \& Impellizzeri, F. M. (2007b). Validity of simple field tests as indicators of match-related 
physical performance in top-level professional soccer players. International journal of sports medicine, 28(3), 228-235. https://doi.org/10.1055/s-2006-924340

Halouani, J., Chtourou, H., Dellal, A., Chaouachi, A., \& Chamari, K. (2017). Soccer small-sided games in young players: rule modification to induce higher physiological responses. Biology of sport, 34(2), 163-168. https://doi.org/10.5114/biolsport.2017.64590

Castagna, C., Varley, M., Póvoas, S., \& D’Ottavio, S. (2017). Evaluation of the Match External Load in Soccer:
Methods Comparison. International journal of sports physiology and performance, 12(4), 490-495.

https://doi.org/10.1123/ijspp.2016-0160

Hoppe, M. W., Baumgart, C., Slomka, M., Polglaze, T., \& Freiwald, J. (2017). Variability of Metabolic Power Data in Elite Soccer Players During Pre-Season Matches. Journal of human kinetics, 58, 233-245.

https://doi.org/10.1515/hukin-2017-0083

\title{
АНАЛІЗ 3ОВНІШНЬОГО ТА ВНУТРІШНЬОГО НАВАНТАЖЕННЯ У ІГРАХ ПОВНИМ СКЛАДОМ 5 НА 5: ВІДМІННОСТІ МІЖ ПОЛЯМИ РІЗНОГО РОЗМІРУ
}

\author{
Джакомо Кофано ${ }^{1 \mathrm{AD}}$, Франческа Д’Еліа ${ }^{2 \mathrm{AD}}$, Андреа Піччінно $^{3 \mathrm{BC}}$, Iтало Саннікандро $^{1 \mathrm{AD}}$ \\ ${ }^{1}$ Університет Фоджа \\ ${ }^{2}$ Університет Салерно \\ ${ }^{3}$ Професійний футбольний тренер із силової і кондиційної підготовки
}

Авторський вклад: А - дизайн дослідження; В - збір даних; C - статаналіз; D - підготовка рукопису; Е - збір коштів

Реферат. Стаття: 6 с., 2 табл., 30 джерел.

Мета дослідження - проаналізувати та зрозуміти особливості внутрішнього та зовнішнього навантаження у вправах ігор повним складом (ІПС), які виконуються на полях різного розміру, визначених як малі ігри повним складом (МIПС) та великі ігри повним складом (ВІПС), відповідно до різних квадратних метрів, призначених кожному гравцю.

Матеріали та методи. Учасники: 22 професійних футболіста (середній вік: 23,59 \pm 4,87 років, вага: 77,8 \pm 7,6 кг; зріст: $183,5 \pm 7,5$ см, стаж тренувань: $13,1 \pm 1,7)$. Вправи IПС проводилися на полі розміром 60 х 54 м (270 м²/на гравця), визначеному як «мале» (МІПС) та на полі розміром $65 \times 60$ м $\left(325 \mathrm{~m}^{2} /\right.$ на гравця), визначеному як «велике» (ВIПС). Під час двох вправ ІПС аналізувалися внутрішнє та зовнішнє навантаження. Вправи ІПС виконувались у 4 підходи по 5 хвилин кожен, з 2 хвилинами пасивного відпочинку між кожним підходом.

Результати. Результати аналізу внутрішнього навантаження показують, як ІПС, проведені на полі МІПС, забез- печують вищі та більш суттєві значення ЧСС ( $<00,0005)$, ніж ті, які з'являються під час вправи, проведеної на полі ВІПС. Значення суб'єктивно сприйманої напруженості також вище під час МІПС, хоча істотної статистичної різниці не спостерігається. Аналіз зовнішнього навантаження у співвідношенні з спостережуваними параметрами показує вищі значення у ВІПС, за винятком кількості прискорень.

Висновки. Стосовно зовнішнього та внутрішнього навантаження, результати дослідження показали, як різниця в $55 \mathrm{~m}^{2} /$ на гравця може кардинально змінити конфігурацію двох вправ. Ці відмінності дозволяють використовувати обидва виміри в межах мікроциклу, але в тренуваннях 3 різними цілями. Найбільш підходящими тренувальними сесіями для ІПС є перша післяматчева сесія, до якої не було дня відпочинку, і четверта сесія за 3 дні до матчу.

Ключові слова: ігри повним складом, зовнішнє навантаження, внутрішнє навантаження, футбол, професійні футболісти.

\section{Information about the authors:}

Giacomo Cofano: giacomo.cofano@unifg.it; https://orcid.org/0000-0001-9973-1740; Master degree in Sciences and techniques of preventive and adapted motor activities, University of Foggia, Italy, Viale Virgilio 16, 71100 Foggia, Italy.

Francesca D'Elia: fdelia@unisa.it; https://orcid.org/0000-0003-1441-8101; Department of Human, Philosophical and Education Sciences, University of Salerno, Italy, Via Giovanni Paolo II, 132 - 84084 - Fisciano (SA), Italy.

Andrea Piccinno: andrea.piccinno@unifg.it; https://orcid.org/0000-0002-4687-6652; Professional soccer strength and conditioning coach, Viale Virgilio 16, 71100 Foggia, Italy.

Italo Sannicandro: italo.sannicandro@unifg.it; https://orcid.org/0000-0003-1284-2136; Department of Humanities, Literature, Cultural Heritage, Education Sciences, University of Foggia, Italy; Professional soccer strength and conditioning coach, Viale Virgilio 16, 71100 Foggia, Italy..

Cite this article as: Cofano, G., D’Elia, F., Piccinno, A., \& Sannicandro, I. (2021). Analysis of the External and Internal Load in 5vs5 Large Sided Games: Differences Between Different Sized Fields. Teoriâ ta Metodika Fizičnogo Vihovannâ, 21(4), $337-342$. https://doi.org/10.17309/tmfv.2021.4.08

Received: 11.10.2021. Accepted: 29.10.2021. Published: 25.12.2021

This work is licensed under a Creative Commons Attribution 4.0 International License (http://creativecommons.org/licenses/by/4.0). 